Marketing in Asia Group

Asian Journal of Business Research

Volume 10 Issue 3, 2020

ISSN 2463-4522 e-ISSN 1778-8933

DOI: $10.14707 / a j b r .200091$

\title{
Role of Connectedness to Nature and Perceived Environmental Responsibility on Green Purchase Behaviour
}

\author{
Jayshree Jaiswal \\ Institute of Management, Nirma University, Ahmedabad, Gujarat, India \\ Seema Bihari \\ Institute of Management, Nirma University, Ahmedabad, Gujarat, India
}

\begin{abstract}
An increase in the consumption of goods and services has led to a detrimental effect on the environment, and there is a need to understand green purchase behaviour. The purpose of this paper is to study the role of connectedness to nature and perceived environmental responsibility on the green purchase behaviour of consumers. The sample comprised of individuals above the age of 20 years from urban parts of India. Data analysis consisted of structural equation modelling and AMOS. The mediation effect of perceived environmental responsibility was assessed using Hayes Process test and Sobel test. The results show that perceived environmental responsibility mediates the relationship between connectedness to nature and green purchase behaviour. Marketing managers can effectively target consumers by triggering a stronger connection to nature and highlighting their responsibility to protect the environment. The study provides insights into consumer psychology and marketing theory and adds to the emergent literature related to consumer green purchasing behaviour in a developing nation.
\end{abstract}

Keywords: Green Purchase Behaviour, Human-nature Relationship, Connectedness to Nature, Perceived Environmental Responsibility, India, Sobel Test

Publication Details: Received 13 Apr 2020; Revised 27 Oct 2020; Accepted 30 Nov 2020 


\section{Introduction}

An increase in the consumption of goods and services has led to a detrimental effect on the environment. The greenness aspect is essential to address the various environmental challenges like pollution, global warming, loss of biodiversity, resource scarcity, etc. (Chen \& Chai, 2010) and to meet the goals of sustainable development (Barbarossa \& De Pelsmacker, 2016). Undertaking green initiatives has both environmental benefits and economic benefits (Ritter et al. 2015). For example, a study conducted on 190 of Fortune 500 companies, reported that green initiatives in 2016 resulted in savings of $\$ 3.7$ billion (The Straits Times, 2019). Sarkar et al. (2019), found that the bonds with strong sustainability attributes had outperformed the bonds with weak sustainability attributes in the past seven years. Corporates have recognised their roles and responsibilities towards protecting nature, and a majority of brands across the globe are making efforts to come up with sustainable initiatives. There is a need for balance between supply-side initiatives by companies and demand-side strategies by the consumers.

The increased awareness among consumers regarding the benefits of engaging in green behaviour can motivate their willingness to purchase green products (Kumar \& Ghodeswar, 2015; Biswas \& Roy, 2015). Consumers can play a role in preventing environmental damage by buying green products. However, there is an observed difference in the attitude of the consumers and their actual purchase behaviour (Young et al., 2010). Grunert and Juhl (1995) reported that consumer household purchases are responsible for $40 \%$ of the total environmental damage. There is a need for consumers to understand the role they can play and the responsibility they have as a citizen in protecting nature. An understanding of consumer purchase behaviour for green products will be helpful for the firms in facilitating the sustainable movement (Thogersen et al., 2015).

Theorists have argued that there exists an interdependent relationship between humans and nature (Nisbet, Zelenski, \& Murphy, 2009; Mayer \& Frantz, 2004). Human beings are dependent on the natural environment both physically and emotionally, and in turn, the fate of species and ecosystems is dependent on the human-beings (Davis, Green \& Reed, 2009). Presently, owing to the shift in the digital era, most of us spend our time indoors, and contact with the surrounding natural world is limited. There is a need to reconnect society with nature to motivate individuals them to work towards sustainability (Bragg, 1996). Major global forums have called for taking appropriate actions and devising strategies to strengthen human-nature relationships (Zylstra et al., 2014).

Existing literature advocated that there is a link between human-nature relationship and sustainability aspects (Ives et al., 2018; Holden 2005; Park et al., 2010; Wilson, 1984). The effect of $\mathrm{CN}$ on measures like conservation behaviour, engagement in proenvironment behaviour, well-being, environmental beliefs, and identity are studied (Brügger, Kaiser, \& Roczen, 2011; Martin \& Czellar, 2016; Olivos \& Clayton, 2017). However, the specific role of $\mathrm{CN}$ in influencing the purchase decisions of the green products is yet not established in the literature. Therefore, the present study aims to understand the influence of CN, specifically on GPB. 
Most of the studies linking $\mathrm{CN}$ with protective environment behaviour have focused on developed western countries. There are calls from researchers to understand CN and to ascertain if $\mathrm{CN}$ is felt similarly among different populations or cultures since responses can generally be more diverse (Restall \& Conrad, 2015). Exploring the role of human- nature relationships in the Indian context can provide exciting insights because Indian tradition and religious belief have always valued the human-nature relationship and given importance to it. Indian culture believes in being in harmony with nature, and it is being reflected and nurtured in a variety of rites and rituals, arts, crafts, and daily lives of Indian people. Human-nature connectedness can be used to promote protective links and to generate a sense of responsibility towards nature.

Environmental responsibility motivates an individual to take initiatives to protect the environment and to promote environmental practices (McDonald et al., 2015). Therefore, we also provide a responsibility-based account by exploring the role of perceived environmental responsibility (PER). There are calls from eco-psychologists to understand the motivating factors like the role of an individual's sense of responsibility to understand the environment behaviours (Yue et al., 2020; Eden, 1993). This study looks at the role of PER in driving GPB through linking CN. The structural relationship between the constructs, namely CN, PER, and GPB and their interactions, is yet to be explored. Through our present study, we aim to explore how $\mathrm{CN}$ among individuals can lead to PER which in turn can promote GPB.

According to the Greendex survey carried out in 2014, India scored 61.4 points and was the top country among the 18 countries included in the study. Survey took consumption patterns of consumers and their concerns for the environment into account. The countries included for comparison are Australia, India, China, the United States, the United Kingdom, etc. (Greendex Ranks 18 Countries Based on Sustainability, 2020). Consumers in Asian countries are increasingly becoming aware of the environmental problems caused due to globalisation ( $\mathrm{Li} \& \mathrm{Su}, 2007$ ). Consumers are willing to take environmentally friendly initiatives, such as the purchase of green products, to reduce the harmful impact on the environment (Saxena \& Khandelwal, 2010).

The changes in consumer behaviour have prompted organisations to promote green products and influence customers to purchase green products (Sreen, Purbey, \& Sadarangani,2018). Moreover, Asian countries are densely populated, and consumers have the power to influence the global economy; therefore, firms offering green products are targeting Asian countries (Jaiswal \& Kant, 2018). Yet, only a few studies have explored the green purchase behaviour of consumers of emerging economies like India (Chan, 2001; Mostafa, 2006; Chen \& Chai, 2010; Yadav \& Pathak, 2016). Therefore, this study aims to address the following research questions in an emerging economy like India and figure 1 depicts the proposed conceptual framework:

(1) What is the role of $\mathrm{CN}$ in influencing GPB?

(2) What is the role of PER in influencing the relationship between $\mathrm{CN}$ and GPB? 
Figure 1: Conceptual Framework

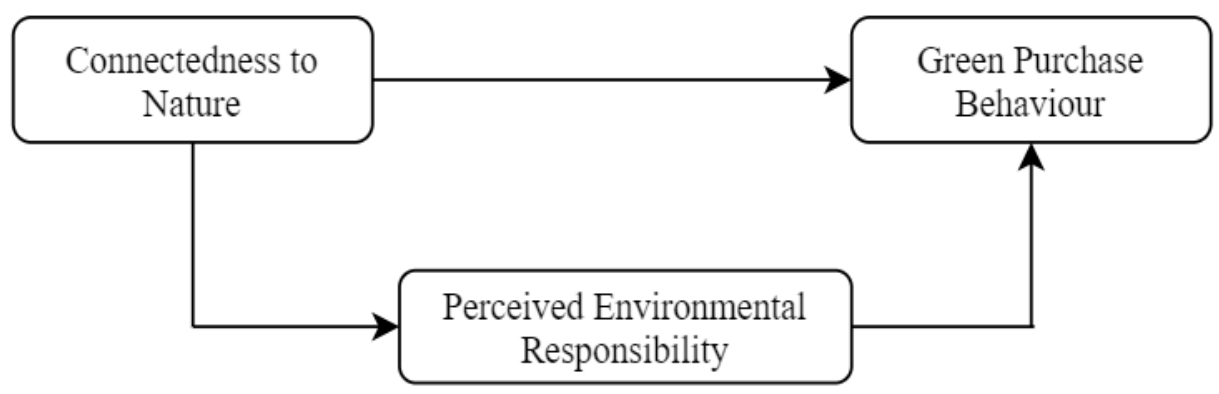

This study contributes to the literature in three ways. Firstly, it adds to the recent call for research in understanding green marketing in Asian countries (Skarmeas \& Leonidou, 2013; Lyon \& Montgomery, 2015). Secondly, this study extends the understanding of the process by which $\mathrm{CN}$ impacts GPB. Specifically, the paper examines the mediating role of PER in the relationship between $\mathrm{CN}$ and GPB. Finally, this study examines the role of $\mathrm{CN}$ on GPB in an emerging economy, providing insights on how to influence the purchase decisions of individuals by imbuing the human-nature connections. The findings from this study add to the existing body of knowledge by explaining the role of CN, PER, and GPB in a developing country. From a business perspective, this study contributes to business by allowing them to understand customer attitudes towards green products better and providing useful insights to better respond to human-nature relationship aspects. Thus, the present study helps marketers in developing sustainable business activities and strategies that are the key to improving competitiveness and for building a strong brand image.

The rest of the paper is organised as follows. First, relevant literature has been reviewed, and appropriate hypotheses have been proposed. Next, we detail the research methodology employed in this study. After that, we present our data analysis and results. Finally, theoretical and managerial implications of the findings are discussed, along with limitations and future research directions.

\section{Literature Review and Hypothesis Development}

\section{Green Purchase Behaviour (GPB)}

Green purchase behaviour refers to "the consumption of products that are benevolent or beneficial to the environment, recyclable or conservable and sensitive or responsive to ecological concerns"(Mostafa, 2007). GPB usually includes eco-friendly carry bags, recycled papers, herbal products, energy-saving bulbs, energy-efficient appliances and vehicles, household products, etc. (Lee, 2008).

Theory of Reasoned Action (TRA) (Fishbein \& Ajzen, 1975) and Theory of Planned Behaviour (TPB) (Ajzen \& Fishbein, 1980) have been widely in different contexts in the field of environmental, behavioural research to understand GPB (Paul et al., 2016; Yadav \& Pathak, 2016). TRA states that consumer behaviour is determined by their intention, which in turn is shaped by the attitude and subjective norms. TPB built on the model of TRA also accounts for perceived behavioural control. However, 
inconsistency in results was identified, and it was observed that consumer behaviour is not only affected by the attitudinal factors, but other factors also play a crucial role in shaping consumer behaviour (Chan, 2001; Chan \& Lau, 2002; Akehurst et al., 2012).

Green consumer behaviour is evolving as an emerging paradigm for marketers, consumer researchers and eco psychologists (Mainardes et al., 2017). Existing research involved in understanding the green behaviour of the consumers has dealt with variables like socio-demographics (Poškus \& Žukauskienè, 2017), environmental consciousness and awareness (Diamantopoulos et al., 2003), green consumption values (Haws, Winterich, \& Naylor, 2014), personal norms (Arvola et al., 2008, Gleim et al., 2013), self-perception (Cornelissen et al., 2008), social motives (Griskevicius, Tybur, \& Van den Bergh, 2010), appeal type (Kronrod et al., 2012), perceived consumer effectiveness (Gleim et al., 2013), willingness to pay more (Singh \& Pandey, 2018), consumer lifestyle (Adnan et al., 2017), etc. However, there is a shift from concrete to more abstract concepts that can drive human-nature relationships (Dong et al., 2020; Stern, 2000). There is an innate need for mankind to connect with other members of the community, contribute to the welfare and become a responsible member of the community. Extended discussions on the relationship between $\mathrm{CN}$ and GPB have been lacking, and more insights into the mechanism need to be explored.

\section{Connectedness to Nature $(\mathrm{CN})$}

As noted by Mayer and Frantz (2004), the influential ecologist Leopold (1949, p. 204) wrote years ago: 'We abuse land because we regard it as a commodity belonging to us. When we see land as a community to which we belong, we may begin to use it with love and respect'. In today's digitised environment, there is limited or no direct interaction with the natural environment (Soga \& Gaston, 2016; Beery et al., 2015). For example, as per a recent report, most people in India spend $85 \%$ of their life indoors- inside homes or offices, commercial or industrial buildings or schools and colleges (Inside story: Indoor pollutants more harmful than those in an outdoor environment, 2020). Concern for the environment can be impacted by a lack of interaction with the natural environment. From this perspective, the development of $\mathrm{CN}$ is essential for fostering green consumerism and promoting green initiatives.

There are two main theoretical routes to consider while describing the construct of CN. First, Wilson (1984) biophilia that takes an emotional route and describes "humanity's innate affinity for and interest in forging connections with the natural world (p. 1)." Second, Schultz (2002) conceptualisation that accounts of the cognitive view of $\mathrm{CN}$ as "the understanding that an individual has of her place in nature, that s/he places on nature and his/her actions that impact the natural environment (p. 67)". $\mathrm{CN}$ has three psychological components: cognitive, affective, and behavioural as well as three core structural components: connectedness, caring, and commitment (Schultz, 2002). 
A detailed look at the existing literature between $\mathrm{CN}$ and environmental behaviour shows that there exists a positive relationship between them. For example, Schultz (2001) found that people who feel more connected to nature include nature in their self-concepts, and thus they are more environmentally friendly. Further, Schultz (2002) proposed that connectedness leads to caring, which, in turn, leads to proenvironmental actions. Mayer and Frantz (2004) found a moderate positive relationship between $\mathrm{CN}$ and pro-environmental behaviours and proposed the modernisation of society as the reason for the moderate relationship. Davis et al. (2009) found that stronger $\mathrm{CN}$ leads to more involvement in a relationship with nature. Klassen (2010) found that people residing in rural areas are more attached to nature in comparison to urban youths because of their lack of direct interaction with nature.

Otto and Pensini (2017) found that emotional CN leads to intrinsic motivation to engage in pro-environmental behaviour as they experience an extension of themselves. A few recent studies also found that $\mathrm{CN}$ is positively related to more proenvironmental behaviours (Mackay \& Schmitt, 2019; Whitburn, Linklater \& Abrahamse, 2019; Jaiswal, 2020). Thus, considering the existing literature, we expect $\mathrm{CN}$ will influence an individuals' tendency to engage in green consumption, such as choosing eco-friendly products. Therefore, it is proposed:

H1 Connectedness to nature will positively influence green purchase behaviour.

\section{Perceived Environmental Responsibility (PER)}

We define PER as the extent to which an individual feels responsible for the environmental harm, and they account only themselves for making efforts to mitigate the effect (Lee, 2009). Consumers have a general tendency to rationalise an offering in terms of the potential benefit and cost involved when buying it. Consumers' decision at any point in time is based on their convenience and economic viability. In the green context, consumer decision making is different from decision making for conventional products. Consumption of green products involves making a sacrifice for others and not think of benefits for oneself (White \& Simpson, 2013). Green products have higher prices as compared to conventional ones, customers who choose to buy green products pay more for the benefit to the environment (Griskevicius et al., 2010). Due to its altruistic nature, an individual must have a strong "other" orientation, sense of responsibility, and willingness to sacrifice their time and preferred activities to protect the environment for the long-term benefits of the Earth and the human race (Allen \& Ferrand, 1999). The role of environmental responsibility needs to be imbued in individuals as they do not feel they have the responsibility for doing everything (Moisander, 2007).

Existing literature supports the view that people who buy or prefer to go green consider it to be a part of their environmental responsibility (Nyborg et al., 2006; Attaran \& Celik, 2015; Klockner, 2013). Greater the sense of responsibility and recognition of the role that one can play in saving the environment and limiting its destruction, more significant is the willingness to make efforts towards going green (Knopman et al., 1999). According to Inglehart (1995), an individual's responsibility for sustainable environmental development shapes his behaviour towards proenvironmental initiatives. Stern et al. (2000) found that a sense of responsibility is 
positively associated with the willingness to perform green behaviour. However, Lee (2009) argued that PER is weak among individuals despite having environmental knowledge and awareness of environmental problems. Such individuals expect the government to work towards environmental protection and provide support through proactive policies. There is inconsistency in results regarding the role of PER in driving green behaviour; therefore, the concept of PER needs more attention. Future research direction should determine measures that build a sense of responsibility among individuals (Paço \& Gouveia Rodrigues, 2016).

Since environmental issues are temporally and socially distant, individuals do not show a sense of responsibility in environmental protection. Considering the Norm Activation Model (Schwartz, 1977), in an altruistic setting, an individual is likely to be aware of the harmful consequences and have a sense of responsibility for their actions. We propose that an individual with a sense of responsibility for the environment, will be willing to engage in GPB. Therefore, it is proposed:

H2 Perceived environmental responsibility will positively influence green purchase behaviour.

Previous research has suggested that those who feel connected to others are more likely to hold environmental values (Berenguer et al., 2005; Evans et al., 2018). Also, experiences in nature lead to increased environmental responsibility and connection to nature (Rosa et al., 2019). Leopold (1949) argued that for people to feel responsible for nature and to engage in eco-friendly acts, they need to feel connected to nature. This explains, to a certain extent, the positive relationship between the sense of connectedness, PER, and environmental behaviour. However, the pathways to this relation are unknown, especially for developing countries (Bratman et al., 2019). We test an underlying mechanism linking the sense of connectedness, and green behaviour runs via the sense of perceived responsibility. We propose that $\mathrm{CN}$ leads to individuals' perceived responsibility for environmental damage, which in turn leads to a higher tendency to prefer eco-friendly products to overcome the damage. A responsibility-based account suggests that consumers who have a perceived sense of environmental responsibility are likely to perform GPB.

H3 Connectedness to nature will positively influence perceived environmental responsibility.

H4 Perceived environmental responsibility will positively mediate the relationship between connectedness to nature and green purchase behaviour.

\section{Research Method}

\section{Sample}

A questionnaire to measure the dependent and independent variables was designed and administered on the target sample. English is the most commonly used language for communication in India; therefore, the questionnaire was developed using the English language only. Educated individuals above the age of 20, and from the urban 
regions of India were contacted for this study. It is found that consumers who are educated and belong to the urban area may have better knowledge and acceptance of green products (Prakash \& Pathak, 2017; Yadav \& Pathak, 2017, Ottman et al., 2006; Lee, 2008). Non-random convenience sampling followed by snowball method was used for data collection. The survey was distributed on email and social networking sites such as Facebook and WhatsApp.

The participants were informed about the purpose of the study and were assured that their identity, along with the responses, would be kept anonymous. Adding a clause of anonymity helps in ensuring that the respondents do not provide socially desirable answers (Podsakoff et al., 2003). The questionnaire was pre-tested on ten postgraduate students from a reputed B- school in India. It is beneficial to perform a pre-test as it helps in refining and identifying potential errors in the questionnaire (Reynolds, Diamantopoulos, \& Schlegelmilch, 1993). Based on the responses of the participants, some changes were made in the questionnaire. After refinement of the questionnaire, it was again pre-tested on 5 participants. Since no significant changes were suggested by the participants, the questionnaire was finalised and administered on the target sample.

In Structural Equation Modelling as a rule of thumb, any number above 200 (critical sample size) is considered to provide sufficient statistical power for data analysis (lter, 1983; Hoe, 2008). In the context of this study, a sample size of 203 is considered sufficient for testing model fit and study hypotheses.

The use of a self-administered questionnaire can lead to common method bias, which can potentially influence the relationship between the variables. The procedural remedies recommended by Podsakoff et al. (2003) have been used to take care of potential common method bias. The participants were assured of anonymity and were encouraged to respond honestly. Harman's single factor test was used to ensure that the common method bias is not a major contributor to the present study. The total variance explained by a single factor was 42 percent, which is below the acceptable value of 50 percent (Malhotra et al. 2006).

The data was collected over two months through an online survey. Response bias is often associated with an online study, and response bias can affect the validity of the questionnaire survey (Nederhof, 1985). Response biases can be reduced by assuring the respondents about the confidentiality of the study. The participants were assured that the research is being conducted for academic purposes. Statistical test was conducted to assess if there was any difference in the early and late responses. T-test of means of old versus new responses does not show any significant differences (Armstrong \& Overton, 1977).

A total of 250 responses were collected, and after filtering out the incomplete answers, a useful sample of 203 responses was used for analysis. Out of the 203 respondents, 52.7 percent were male, and 47.3 percent were female. 37.9 percent of the respondents were within the age group of 18-25 years, 48.8 percent of respondents were in the age group of 26-35 years, and 13.3 percent were from the age group of 36 years and above. The sample comprised of both students (31.5 percent) and working professionals (68.5 percent). 


\section{Measures}

This study used the measurement scales which have been previously validated in literature. Five-point Likert type scales ranging from 1 (strongly disagree) to 5 (strongly agree) were used for all measures. GPB and PER were measured using a scale developed by Lee (2009). CN was measured using the scale developed by Mayer and Frantz (2004). Participants were also requested to provide their demographic information (age and gender). We have statistically controlled for age and gender, as these two variables can confound the results.

\section{Analysis and Results}

SPSS version 24 and AMOS version 20 was used to assess the model. A two-stage structural equation modelling was used to evaluate the measurement and structural model. The reliability and validity of the measurement model were assessed using confirmatory factor analysis (CFA). Structural models were used to determine the goodness of fit of the model and to test the hypothesis (Hair et al., 2015).

\section{Exploratory Factor Analysis}

Before assessing the measurement model, EFA was used to identify the factors (Gerbing \& Anderson, 1988). The responses to the items representing the three variables were factor analysed using maximum likelihood procedure with ProMax rotation. Through a series of exploratory factor analysis, a final list of 16 items (six for $\mathrm{CN}$, four for PER and six for GPB) was identified. These items were selected based on factor loadings and commonalities. These 16 items were again run for factor analysis. Three factors with Eigenvalue of greater than 1.0 that accounted for $60.47 \%$ of total variance were generated. Table I represents the pattern matrix generated by exploratory factor analysis.

Table 1: Exploratory Factor Analysis

\begin{tabular}{|l|l|l|l|}
\hline Variables and items & Factor 1 & Factor 2 & Factor 3 \\
\hline Connectedness to Nature & .10 & .64 & \\
\hline I often feel a kinship with animals and plants. & .76 & \\
\hline $\begin{array}{l}\text { I feel as though I belong to the Earth as equally as it belongs to } \\
\text { me. }\end{array}$ & & .59 & \\
\hline $\begin{array}{l}\text { I have a deep understanding of how my actions affect the natural } \\
\text { world. }\end{array}$ & .18 & .71 & \\
\hline I often feel part of the web of life. & .78 & \\
\hline $\begin{array}{l}\text { I feel that all inhabitants of Earth, human, and nonhuman, share a } \\
\text { common 'life force. }\end{array}$ & & .80 & \\
\hline $\begin{array}{l}\text { Like a tree can be part of a forest, I feel embedded within the } \\
\text { broader natural world. }\end{array}$ & & .10 & \\
\hline Green Purchase Behaviour & .12 & \\
\hline I often buy products that are against animal-testing. & .72 & .68 & \\
\hline $\begin{array}{l}\text { I often buy products that contain no or fewer chemical } \\
\text { ingredients. }\end{array}$ & & .85 & .74 \\
\hline I often buy products that are labelled as environmentally safe. & & \\
\hline $\begin{array}{l}\text { When I consider buying a product, I will look for a certified } \\
\text { environmentally safe or organic stamp. }\end{array}$ & & & \\
\hline I often buy products that support fair community trades. & .75 & .69 & \\
\hline \begin{tabular}{l} 
I often buy products that use recycled/ recyclable packaging. \\
\hline
\end{tabular} & & & \\
\hline
\end{tabular}




\begin{tabular}{|l|l|l|l|}
\hline Perceived Environmental Responsibility & & & .71 \\
\hline I should be responsible for protecting our environment & & & .94 \\
\hline $\begin{array}{l}\text { *Environmental protection is the responsibility of the } \\
\text { Government, not mine. }\end{array}$ & & .93 \\
\hline $\begin{array}{l}\text { *Environmental protection is the responsibility of environmental } \\
\text { organisations, not mine. }\end{array}$ & .18 & .74 \\
\hline $\begin{array}{l}\text { I am willing to take up the responsibility to protect the } \\
\text { environment. }\end{array}$ & & & .74 \\
\hline
\end{tabular}

*Reverse coded items

\section{Measurement Model}

To validate all the constructs under investigation, CFA was performed using AMOS via the maximum likelihood procedure. The assessment of the goodness of fit was done using multiple indicators: ratio of chi-square and degree of freedoms, the goodness of fit index, adjusted goodness of fit index (AGFI), normed fit index (NFI) and comparative fit index (CFI), root mean square residual (RMR), and root mean square error of approximation (RMSEA) (Hair et al., 2015; Malhotra \& Dash, 2015). The value for goodness of fit statistics (Chi-square $(\chi 2) / \mathrm{df}=1.28, \mathrm{GFI}=0.92, \mathrm{AGFI}=$ $0.90, \mathrm{NFI}=0.913 \mathrm{CFI}=0.98, \mathrm{RMSEA}=0.03)$ was found to meet the acceptance criterion recommended by Hair et al. (2015).

\section{Reliability and Validity of the Constructs}

The model was found to have acceptable values on the different indices of the goodness of fit. Table 2 presents Cronbach's $\alpha$, Composite reliability (C.R), Standardised factor loadings, and Average variance extracted (AVE). The alpha values for the three constructs were above the threshold limit of 0.70 (Hair et al., 2015; Malhotra \& Dash, 2015). The measures that are useful in establishing convergent validity are factor loading, composite reliability, and average variance extracted. The standardised factor loadings of all the items were between the values of 0.671 to 0.902 . The values of composite reliability meet the acceptance criterion suggested by Hair et al., 2015.

Table 2: Standardised Factor Loadings, Composite Reliability, Average, Variance Extracted, and Cronbach's $\alpha$

\begin{tabular}{|l|l|l|l|l|l|}
\hline Items & Variables & Factor Loading & $\begin{array}{l}\text { Composite } \\
\text { Reliability }\end{array}$ & AVE & Cronbach's $\boldsymbol{\alpha}$ \\
\cline { 1 - 1 } CN6 & \multirow{2}{*}{$\begin{array}{l}\text { Connectedness to } \\
\text { Nature }\end{array}$} & 0.726 & 0.877 & 0.543 & 0.876 \\
CN7 & & 0.796 & & & \\
CN8 & & 0.689 & & & \\
CN9 & & 0.671 & & \\
CN10 & & 0.762 & & & \\
& & 0.771 & & & \\
\hline
\end{tabular}




\begin{tabular}{|c|c|c|c|c|c|}
\hline PER1 & \multirow{4}{*}{$\begin{array}{l}\text { Perceived } \\
\text { Environmental } \\
\text { Responsibility }\end{array}$} & 0.787 & \multirow[t]{4}{*}{0.914} & \multirow[t]{4}{*}{0.728} & \multirow[t]{4}{*}{0.913} \\
\hline PER2 & & 0.890 & & & \\
\hline PER3 & & 0.902 & & & \\
\hline PER6 & & 0.828 & & & \\
\hline GPB2 & \multirow{6}{*}{$\begin{array}{l}\text { Green Purchase } \\
\text { Behaviour }\end{array}$} & 0.772 & \multirow[t]{6}{*}{0.889} & \multirow[t]{6}{*}{0.573} & \multirow[t]{6}{*}{0.889} \\
\hline GPB3 & & 0.742 & & & \\
\hline GPB4 & & 0.805 & & & \\
\hline GPB5 & & 0.736 & & & \\
\hline GPB6 & & 0.759 & & & \\
\hline GPB7 & & 0.724 & & & \\
\hline
\end{tabular}

The value of the average variance extracted (AVE) ranged from 0.543 to 0.728 , which is above the value suggested as an acceptance criterion (Hair et al., 2015). Discriminant validity of the construct is established if the square root of AVE of each of the constructs is larger than the squared correlation between the constructs (Hair et al., 2015), and the results are presented in table 3.

Table 3: Results of Discriminant Validity of the Measurement Model

\begin{tabular}{|l|l|l|l|}
\hline & CN & PER & GPB \\
\hline CN & $\mathbf{. 7 3 6}$ & & \\
\hline PER & .504 & $\mathbf{8 5 3}$ & \\
\hline GPB & .649 & .543 & $\mathbf{. 7 5 6}$ \\
\hline
\end{tabular}

Note: Diagonal values show the square root of AVE for each construct.

\section{Structural Model}

The evaluation of measurement model, was followed by estimation of the structural model analysing the goodness of fit statistics (Chi-square $(\chi 2) / \mathrm{df}=1.337, \mathrm{GFI}=0.914$, AGFI $=0.888, \mathrm{IFI}=0.977, \mathrm{TLI}=0.972, \mathrm{NFI}=0.913 \mathrm{CFI}=0.976, \mathrm{RMSEA}=0.041$ ). The goodness of statistics was found to meet the acceptance criterion recommended by Hair et al. (2015). The proposed hypotheses were assessed using the path diagram. The standardised regression weights and P-values in table 4 reported the effect of independent variables on the dependent variable.

Table 4: Standardized Regression Weights and P-Values

\begin{tabular}{|l|l|l|l|l|l|}
\hline Hypothesis & Path & t-value & Estimates & p-value & Result \\
\hline H1 & PER <---CN & 6.364 & .713 & $* * *$ & Supported \\
\hline H2 & GPB<---CN & 5.824 & .629 & $* * *$ & Supported \\
\hline H3 & GPB<---PER & 3.868 & .256 & $* * *$ & Supported \\
\hline
\end{tabular}


The value of adjusted $\mathrm{R}$ square represents the explanatory power of the independent variables on the dependent variable. There are two dependent variables in the proposed model, namely, PER and GPB. $\mathrm{CN}$ is the independent variable. The results suggested that $\mathrm{H} 1, \mathrm{H} 2$, and $\mathrm{H} 3$ are accepted.

\section{Test for Mediation}

Data were analysed with Hayes (2013) PROCESS macro to test for mediation using linear regression. With an R-squared value of $0.406(\mathrm{~F}(2,200)=68.29, \mathrm{p}=0.000)$, the mediation model is significant. A beta weight $(\beta)$ of $0.27(\mathrm{t}=4.83, \mathrm{p}=0.000)$ indicates a positive relationship. The analysis of the mediation effect of PER between $\mathrm{CN}$ and GPB showed that the total effect of $\mathrm{CN}$ on GPB was $\beta=0.44$, and the direct effect after controlling for the mediator was $\beta=0.33$. It can be inferred that PER is, a mediator as there is a reduction in the $\beta$-weight (from 0.44 to 0.33 ). The significance of the mediation is determined by obtaining $95 \%$ bias-corrected bootstrap confidence intervals (CI) from 5000 bootstrap samples (Hayes, 2013). Mediation is found to be significant when the CI does not include zero. The results from this procedure suggested that PER significantly mediates the relationship between $\mathrm{CN}$ and GPB (CI $=0.056 / 0.170)$. A significant Sobel test $(\mathrm{t}$ statistic $=4.09, \mathrm{p}<.000)$ confirms the results, thus supporting the $\mathrm{H} 4$.

\section{Discussion}

The adoption of green behaviour by the consumers has triggered the marketers to offers green products and product which are safe to the environment (Davis 1993; Ottman \& Books, 1998). However, there is uncertainty about the actual purchase behaviour of consumers in the real market place. An individual's concern for the environment may not certainly transform into actual green behaviour. The present study provides a deeper understanding of the green purchase behaviour of consumers by exploring the role of connectedness to nature and perceived environmental responsibility. Asian markets are embracing the concept of 'going green' (Ottman et al., 2006), and this study explores the green purchase behaviour of Indians.

The conceptual framework suggested in this study explores the mediating effect of PER on the relationship between CN and GPB. Results support the hypothesis H1 and confirm a positive association of $\mathrm{CN}$ with GPB. These findings resonate with the existing literature that supports the view that a positive relationship exists between $\mathrm{CN}$ and pro-environmental behaviour/sustainability aspects (Schultz, 2001; Mayer \& Frantz, 2004). The effect of $\mathrm{CN}$ as an independent variable is measured on various dependent variables like conservation behaviour, engagement in pro-environment behaviour, well-being, environmental beliefs, and identity (Martin \& Czellar, 2016; Olivos \& Clayton, 2017). The role of $\mathrm{CN}$ in influencing purchasing decisions of the green products is explored through the present work by linking human-nature relationship and sustainability aspects. We identified a positive relationship between $\mathrm{CN}$ and GPB which further strengthens the need of development of $\mathrm{CN}$ for fostering green consumerism and promoting green initiatives. 
In the existing literature, researchers are emphasising on the need to focus on role of environmental responsibility to drive green behaviour. Still, most of the existing studies have largely focused on the responsibility aspect from an organisational point of view and have explored the effect of corporate social responsibility (CSR) or corporate environmental responsibility (CER) on green consumption (Yue et al., 2020). The role of consumer's environmental responsibility in promoting green behaviour has recently attracted the attention of the researchers, but studies are still scarce. Therefore, through the present work, we proposed a mechanism to explain the positive effect of consumers' connectedness to nature on green purchase intention, which specifically reveals that PER act as an essential bridge in promoting green purchase intention. We explained that there is a need to bring consciousness among consumers by making them responsible for their purchase behaviour for the betterment of environmental welfare. Results support hypothesis H2 that PER had a positive relationship with GPB.

Furthermore, the result also supports the $\mathrm{H} 3$ that $\mathrm{CN}$ also influence PER positively. We extended Klockner (2013) findings that individuals' PER is likely to affect their environmentally significant behaviour by exploring the role of PER in influencing GPB in an Asian context. The result also supports the hypothesis $\mathrm{H} 4$ that $\mathrm{CN}$ leads to GPB through the mediating role of PER. We extended Leopold (1949) findings that $\mathrm{CN}$ eventually leads to responsible behaviour towards nature. The responsibilitybased account argues that in order to make people feel responsible for nature and they need to feel connected to nature.Individuals who feel themselves as connected to nature are likely to act as environmentally responsible consumers; in turn, they act more pro-environmentally (Schultz, 2002).

\section{Limitation and Future Research}

Since the measures used in the study are based on self-reports of past behaviours or predictions about future actions, they might be subjected to the response error owing to the social desirability effect. We used a cross-sectional study design; therefore, the changes in the consumer's attitude and their behavioural intentions over time cannot be measured. The sample used in the study is based on convenience sampling and from the people residing in the urban region in India. Non-random sampling limits the representativeness of sample, and the results cannot apply to the rural population. Cultural issues that vary across countries may pose the problem of the generalizability of the study.

The potential impact of social desirability biases on consumer's responses to green behaviour can be examined in future research studies. The representativeness can improve in future studies by randomly taking the population from dispersed locations, and including the rural population. The present study could be replicated in another cultural context outside India. The change in consumer attitude and behavioural intention over a period can be better ascertained with the help of a longitudinal study. Future research may consider other factors that influence $\mathrm{CN}$ among consumers, such as environmental consciousness and ecological values as past studies have found an association of these variables with green behaviour (Haws et al., 2014; Hartmannet al., 2016). The effect of CN and PER could also be investigated on other types of proenvironmental behaviours like reuse, recycle, reduce. Additional variables related to 
firms and product like brand image, price, advertising, quality etc can also explored to generate insights. Other theoretical frameworks like Theory of Planned Behaviour, Human Values theory can be also applied to link CN with GPB.

\section{Conclusion}

Presently, marketers are attempting to promote green products by either highlighting the benefits of buying green products or by emphasising on the negative consequences of not purchasing a green product. However, these efforts are not useful in bringing the desired long-term sustained behaviour change among consumers. This study highlights the importance of human-nature relationship and has identified $\mathrm{CN}$ as an instrumental factor in shaping the GPB. It is of paramount importance to understand how $\mathrm{CN}$ is linked to indicators of green behaviour to foster green purchase behaviour. This study attempts to empirically validate the effect of $\mathrm{CN}$ along with PER on consumer's GPB. The results suggest that consumers who will feel connected to nature will decide to purchase green products because they will feel mutually responsible for causing environmental degradation and believe that it is their responsibility to save the environment. Such an experiential human-nature relationship is useful in building commitment towards nature and in translating an individual's environmental concern into behaviour.

\section{Practical Implications for Asian Business}

The findings of the present work provide insights to the academicians, marketers, and policymakers aiming to promote the widespread adoption of green products especially in the emerging economy. Extant literature discusses most of the consumer behaviour models in the western context, and little attention is given to investigate the validity of these models under other cultural settings (Khare, 2015). Most behavioural theories guided by the psychological factors, which in turn are sensitive to the cultural values of an individual. Thus, we contributed to the knowledge gaps of the human-nature relationship link by exploring the influence of CN, PER on GPB in an Indian (nonwestern) context.The findings from the study highlights the importance of perceived environmental responsibility in influencing a consumer's green purchase behaviour. The inclusion of PER in the study exploring the relationship between $\mathrm{CN}$ and GPB helps in identifying the underlying situational factor that affects consumer behaviour.

The implications of the present work for marketers are manifold, and the findings will help marketers to reach out the right consumers. India is one of the biggest consumer markets in Asia, with a great potential for green products, therefore it's imperative for marketers to know about the factors that influence consumer's GPB. Knowledge of predictors of GPB may help in the development of appropriate marketing strategies to address consumers' attitude-behavior gap, thereby increasing the purchase of green products. The results suggest that it is vital for consumers to feel their responsibility toward environment to contribute towards green purchase behavior. Overall, this study contributes to a better understanding of the process by which $\mathrm{CN}$ influences GPB in an emerging economy. 
By showing the role of PER in the effect of $\mathrm{CN}$ on GPB, this study proposes that managers can adapt their marketing communications and strategies accordingly. Advertising campaigns can be designed to highlight an individual's role and responsibility in protecting the environment. Such advertisements can trigger strong emotional connection to nature and result in environmental responsible behavior. Emerging technologies such as short mobile videos and live mobile streaming, virtual reality, and augmented reality can be effectively used to increase intimacy with nature, by creating direct and indirect nature-related experiences (Dong et al., 2020). Communication, labelling and packaging can play important role in informing the consumers about the eco-friendly product.

Marketers can also play a role in increasing customer's perceived environmental responsibility by educating customers about environmental issues and ways to address those issues (Lai \& Cheng, 2016). Customers need to understand that they play a significant role in conserving the environment by purchasing green products and the damage caused to environment by adopting non-environmentally friendly behavior. Marketers can design advertisement that highlight the pros and cons associated with being responsible towards nature.

Policymakers can also effectively emphasise the emotion of $\mathrm{CN}$ among individuals to promote people's passion for nature. It is important to understand the role that $\mathrm{CN}$ and PER can play in promoting green purchase behaviour. Policy makers need to educate consumers about the role that consumers can play in protecting the environment. With the help of proper campaigns and billboards, the beauty of nature can be articulated to promote individual desire to care for and be close to nature so that they can "feel right" about and develop a strong preference towards green products. Thus, public policymakers can encourage GPB effectively by enhancing CN. Marketing messages aiming to promote the purchase of green products should focus more on the emotional aspects of building human-nature relationship than the rational aspects. It is of importance to make people realise that if they change their behaviour at an individual level then they can save nature. Messages should make emphasis that actions we take are responsible for degrading the environment and therefore we in turn are responsible for protecting the environment through the purchase of environmentally friendly products. Further, policy makers can design and implement regulations that promote environmental responsible behaviour from the consumers, so that perceived environmental responsibility starts to affect the behaviour of consumers. For example: banning the use of plastic bags can influence the customer to either carry bags or purchase environmentally friendly bags. 


\section{References}

Adnan, N., Nordin, S. M., Rahman, I., \& Noor, A., (2017), “Adoption of green fertiliser technology among paddy farmers: A possible solution for Malaysian food security", Land Use Policy, vol. 63, pp. 38-52.

Allen, J. B., \& Ferrand, J. L., (1999), "Environmental locus of control, sympathy, and pro environmental behaviour: A test of Geller's actively caring hypothesis", Environment and Behaviour, vol. 31, no. 3, pp. 338-353.

Anderson, J. C., \& Gerbing, D. W., (1988), "Structural equation modelling in practice: A review and recommended two-step approach", Psychological Bulletin, vol. 103, no. 3, p.411.

Armstrong, J. S., \& Overton, T. S., (1977), "Estimating nonresponse bias in mail surveys", Journal of Marketing Research, vol. 14, no. 3, pp. 396-402.

Arvola, A., Vassallo, M., Dean, M., Lampila, P., Saba, A., Lähteenmäki, L., \& Shepherd, R., (2008), "Predicting intentions to purchase organic food: The role of affective and moral attitudes in the theory of planned behaviour", Appetite, vol. 50, no. 2-3, pp. 443-454.

Attaran, S., \& Celik, B. G., (2015), "Students' environmental responsibility and their willingness to pay for green buildings", International Journal of Sustainability in Higher Education, vol. 16, no. 3, pp. 327-340.

Barbarossa, C., \& De Pelsmacker, P., (2016), "Positive and negative antecedents of purchasing eco-friendly products: A comparison between green and non-green consumers", Journal of Business Ethics, vol. 134, no. 2, pp. 229-247.

Beery, T., Jönsson, K. I., \& Elmberg, J., (2015), "From environmental connectedness to sustainable futures: Topophilia and human affiliation with nature", Sustainability, vol. 7, no. 7, pp. 8837-8854.

Berenguer, J., Corraliza, J. A., \& Martin, R., (2005), "Rural-urban differences in environmental concern, attitudes, and actions", European Journal of Psychological Assessment, vol. 21, no. 2, pp. 128-138.

Biswas, A., \& Roy, M., (2015), "Green products: An exploratory study on the consumer behaviour in emerging economies of the East", Journal of Cleaner Production, vol. 87, pp. 463-468.

Bragg, E. A., (1996), "Towards ecological self: Deep ecology meets constructionist selftheory", Journal of Environmental Psychology, vol. 16, no. 2, pp. 93-108.

Bratman, G. N., Anderson, C. B., Berman, M. G., Cochran, B., de Vries, S., Flanders, J., \& Daily, G. C., (2019), "Nature and mental health: An ecosystem service perspective", Science Advances, vol. 5, no. 7, pp. 1-14.

Brügger, A., Kaiser, F. G., \& Roczen, N., (2011), "One for all? Connectedness to nature, inclusion of nature, environmental identity, and implicit association with nature", European Psychologist, vol. 16, no. 4, pp. 324-333.

Chen, T. B., \& Chai, L. T., (2010), "Attitude towards the environment and green products: Consumers' perspective", Management Science and Engineering, vol. 4, no. 2, pp. 2739.

Clayton, L. W., (2003), Identity and the natural environment: The psychological significance of nature, MIT Press, London.

Cornelissen, G., Pandelaere, M., Warlop, L., \& Dewitte, S., (2008), "Positive cueing: Promoting sustainable consumer behaviour by cueing common environmental behaviours as environmental", International Journal of Research in Marketing, vol. 25, no. 1 , pp. 46-55.

Curlo, E., (1999), "Marketing strategy, product safety, and ethical factors in consumer choice", Journal of Business Ethics, vol. 21, no. 1, pp. 37-48.

Davis, J. J., (1993), "Strategies for environmental advertising", Journal of Consumer Marketing, vol. 10, no. 2, pp. 19-36. 
Davis, J. L., Green, J. D., \& Reed, A., (2009), "Interdependence with the environment: Commitment, interconnectedness, and environmental behaviour", Journal of Environmental Psychology, vol. 29, no. 2, pp. 173-180.

Dong, X., Liu, S., Li, H., Yang, Z., Liang, S., \& Deng, N., (2020), "Love of nature as a mediator between connectedness to nature and sustainable consumption behaviour", Journal of Cleaner Production, vol. 242, p. 118451.

Diamantopoulos, A., Schlegelmilch, B. B., Sinkovics, R. R., \& Bohlen, G. M., (2003), "Can socio-demographics still play a role in profiling green consumers? A review of the evidence and an empirical investigation", Journal of Business Research, vol. 56, no. 6, pp. 465-480.

Eden, S., (1993), "Constructing environmental responsibility: Perceptions from retail business", Geoforum, vol. 24, no. 4, pp. 411-421.

Evans, G. W., (2019), "Projected behavioural impacts of global climate change", Annual Review of Psychology, vol. 70, pp. 449-474.

Ellen, P. S., Webb, D. J., \& Mohr, L. A., (2006), "Building corporate associations: Consumer attributions for corporate socially responsible programs", Journal of the Academy of Marketing Science, vol. 34, no. 2, pp. 147-157.

Gleim, M. R., Smith, J. S., Andrews, D., \& Cronin Jr, J. J., (2013), "Against the green: A multi-method examination of the barriers to green consumption", Journal of Retailing, vol. 89, no. 1, pp. 44-61.

Griskevicius, V., Tybur, J. M., \& Van den Bergh, B., (2010), "Going green to be seen: Status, reputation, and conspicuous conservation", Journal of Personality and Social Psychology, vol. 98, no. 3, p. 392.

Grunert, S. C., \& Juhl, H. J., (1995), "Values, environmental attitudes, and buying of organic foods", Journal of Economic Psychology, vol. 16, no. 1, pp. 39-62.

Hair, J. F., Black, W. C., Babin, B. J., Anderson, R. E., \& Tatham, R. L., (1998), Multivariate data analysis, Prentice Hall, New Jersey.

Haws, K. L., Winterich, K. P., \& Naylor, R. W., (2014), "Seeing the world through greentinted glasses: Green consumption values and responses to environmentally friendly products", Journal of Consumer Psychology, vol. 24, no. 3, pp. 336-354.

Hoe, S. L., (2008), "Issues and procedures in adopting structural equation modelling technique", Journal of Applied Quantitative Methods, vol. 3, no. 1, pp. 76-83.

Hoelter, J. W., (1983), "The analysis of covariance structures: Goodness-of-fit indices", Sociological Methods \& Research, vol. 11, no. 3, pp. 325-344.

Holden, A., (2005), "Achieving a sustainable relationship between common pool resources and tourism: The role of environmental ethics", Journal of Sustainable Tourism, vol. 13, no. 4, pp. 339-352.

Hoot, R. E., \& Friedman, H., (2010), "Connectedness and environmental behaviour: Sense of interconnectedness and pro-environmental behaviour", Transpersonal Studies, vol. 30, no. $1-2$, pp. 89-100.

Inglehart, R., (1995), "Public support for environmental protection: Objective problems and subjective values in 43 societies", Political Science and Politics, vol. 28, no. 1, pp. 5772.

Jaiswal, D., \& Kant, R., (2018), "Green purchasing behaviour: A conceptual framework and empirical investigation of Indian consumers", Journal of Retailing and Consumer Services, vol. 41, pp. 60-69.

Jaiswal, J., (2020), "A conceptual framework to understand the role of anthropomorphism in driving circular economy", Academy of Marketing Studies Journal, vol. 24, no. 1.

Joshi, Y., \& Rahman, Z., (2015), "Factors affecting green purchase behaviour and future research directions", International Strategic Management Review, vol. 3, no. 1-2, pp. 128-143.

Khare, A., (2015), "Antecedents to green buying behaviour: A study on consumers in an emerging economy", Marketing Intelligence \& Planning, vol. 33, no. 3, pp. 309-329.

Klassen, M., (2010), Connectedness to nature: Comparing rural and urban youths' relationships with nature, Master's Thesis, pp. 1-157. 
Klöckner, C. A., (2013), "A comprehensive model of the psychology of environmental behaviour - A meta-analysis", Global Environmental Change, vol. 23, no. 5, pp. 10281038.

Knopman, D. S., Susman, M. M., \& Landy, M. K., (1999), "Civic environmentalism: tackling tough land-use problems with innovative governance", Environment: Science and Policy for Sustainable Development, vol. 41, no. 10, pp. 24-32.

Kronrod, A., Grinstein, A., \& Wathieu, L., (2012), "Go green! Should environmental messages be so assertive?", Journal of Marketing, vol. 76, no. 1, pp. 95-102.

Kumar, P., \& Ghodeswar, B. M., (2015), "Factors affecting consumers' green product purchase decisions", Marketing Intelligence \& Planning, vol. 33, no. 3, pp. 330-347.

Lai, C.K. and Cheng, E.W., 2016. Green purchase behavior of undergraduate students in Hong Kong. The Social Science Journal, 53(1), pp.67-76.

Lee, J. S., Hsu, L. T., Han, H., \& Kim, Y., (2010), "Understanding how consumers view green hotels: How a hotel's green image can influence behavioural intentions", Journal of Sustainable Tourism, vol. 18, no. 7, pp. 901-914.

Lee, K., (2008), "Opportunities for green marketing: Young consumers", Marketing Intelligence \& Planning, vol. 26, no. 6, pp. 573-586.

Lee, K., (2009), "Gender differences in Hong Kong adolescent consumers' green purchasing behaviour", Journal of Consumer Marketing, vol. 23, no. 1, pp. 21-44.

Li, J. J., \& Su, C., (2007), "How face influences consumption", International Journal of Market Research, vol. 49, no. 2, pp. 237-256.

Lyon, T. P., \& Montgomery, A. W., (2015), "The means and end of greenwash", Organisation \& Environment, vol. 28, no. 2, pp. 223-249.

McDonald, S., Oates, C. J., Thyne, M., Timmis, A. J., \& Carlile, C., (2015), "Flying in the face of environmental concern: Why green consumers continue to fly", Journal of Marketing Management, vol. 31, no. 13-14, pp. 1503-1528.

Mainardes, E. W., de Araujo, D. V. B., Lasso, S., \& Andrade, D. M., (2017), "Influences on the intention to buy organic food in an emerging market", Marketing Intelligence \& Planning, vol. 35, no. 7, pp. 858-876.

Malhotra, N. K., \& Dash, S., (2015), Marketing research: An applied orientation, Pearson, New York.

Martin, C., \& Czellar, S., (2016), "The extended inclusion of nature in self scale", Journal of Environmental Psychology, vol. 47, pp. 181-194.

Mayer, F. S., \& Frantz, C. M., (2004), "The connectedness to nature scale: A measure of individuals' feeling in community with nature", Journal of Environmental Psychology, vol. 24, no. 4, pp. 503-515.

Moisander, J., (2007), "Motivational complexity of green consumerism", International Journal of Consumer Studies, vol. 31, no. 4, pp. 404-409.

Mostafa, M. M., (2007), "Gender differences in Egyptian consumers' green purchase behaviour: The effects of environmental knowledge, concern and attitude", International Journal of Consumer Studies, vol. 31, no. 3, pp. 220-229.

Nederhof, A. J., (1985), "Methods of coping with social desirability bias: A review", European Journal of Social Psychology, vol. 15, no. 3, pp. 263-280.

Nisbet, E. K., Zelenski, J. M., \& Murphy, S. A., (2009), "The nature relatedness scale: Linking individuals' connection with nature to environmental concern and behaviour", Environment and Behaviour, vol. 41, no. 5, pp. 715-740.

Nyborg, K., Howarth, R. B., \& Brekke, K. A., (2006), "Green consumers and public policy: On socially contingent moral motivation", Resource and Energy Economics, vol. 28, no. 4, pp. 351-366.

Olivos, P., \& Clayton, S., (2017), "Self, nature and well-being: Sense of connectedness and environmental identity for quality of life", In Handbook of environmental psychology and quality of life research (pp. 107-126), Springer.

Ottman, J., \& Books, N. B., (1998), "Green marketing: Opportunity for innovation", Journal of Sustainable Product Design, vol. 60, no. 7, pp. 136-167. 
Ottman, J. A., Stafford, E. R., \& Hartman, C. L., (2006), “Avoiding green marketing myopia: Ways to improve consumer appeal for environmentally preferable products", Environment: Science and Policy for Sustainable Development, vol. 48, no. 5, pp. 2236.

Otto, S., \& Pamela, P., (2017), "Nature-based environmental education of children: Environmental knowledge and connectedness to nature, together, are related to ecological behaviour", Global Environmental Change, vol. 47, pp. 88-94.

Oyedele, A., \& Dejong, P., (2013), "Consumer readings of green appeals in advertisements", Journal of Promotion Management, vol. 19, no. 4, pp. 435-451.

Paco, A., \& Gouveia, R. R., (2016), "Environmental activism and consumers' perceived responsibility", International Journal of Consumer Studies, vol. 40, no. 4, pp. 466-474.

Park, B. J., Tsunetsugu, Y., Kasetani, T., Kagawa, T., \& Miyazaki, Y., (2010), "The physiological effects of Shinrin-yoku (taking in the forest atmosphere or forest bathing): Evidence from field experiments in 24 forests across Japan", Environmental Health and Preventive Medicine, vol. 15, no. 1, p.18.

Podsakoff, P. M., MacKenzie, S. B., Lee, J. Y., \& Podsakoff, N. P., (2003), "Common method biases in behavioural research: A critical review of the literature and recommended remedies", Journal of Applied Psychology, vol. 88, no. 5, p. 879.

Poškus, M. S., \& Žukauskienè, R., (2017), "Predicting adolescents' recycling behaviour among different big five personality types", Journal of Environmental Psychology, vol. 54, pp. 57-64.

Prakash, G., \& Pathak, P., (2017), "Intention to buy eco-friendly packaged products among young consumers of India: A study on developing nation", Journal of Cleaner Production, vol. 141, pp. 385-393.

Restall, B., \& Conrad, E., (2015), "A literature review of connectedness to nature and its potential for environmental management", Journal of Environmental Management, vol. 159, pp. 264-278.

Reynolds, N., Diamantopoulos, A., \& Schlegelmilch, B., (1993), "Pre-testing in questionnaire design: A review of the literature and suggestions for further research", Market Research Society Journal, vol. 35, no. 2, pp. 1-11.

Rosa, C. D., Collado, S., Profice, C. C., \& Larson, L. R., (2019), "Nature-based recreation associated with connectedness to nature and leisure satisfaction among students in Brazil", Leisure Studies, vol. 38, no. 5, pp. 682-691.

Sarkar, J. G., Sarkar, A., \& Yadav, R., (2019), "Brand it green: Young consumers' brand attitudes and purchase intentions toward green brand advertising appeals", Young Consumers, vol. 20, no. 3, pp. 190-207.

Saxena, R., \& Khandelwal, P. K., (2010), "Can green marketing be used as a tool for sustainable growth?: A study performed on consumers in India - An emerging economy, International Journal of Environmental, Cultural, Economic \& Social Sustainability, vol. 6, no. 2, pp. 278-291.

Schultz, P. W., (2001), "The structure of environmental concern: Concern for self, other people, and the biosphere", Journal of Environmental Psychology, vol. 21, no. 4, pp. 327-339.

Schultz, P. W., (2002), "Inclusion with nature: The psychology of human-nature relations", Psychology of Sustainable Development, pp. 61-78.

Schwartz, S. H., (1977), "Normative influences on altruism", Advances in Experimental Social Psychology, vol. 10, no. 1, pp. 221-279.

Singh, G., \& Pandey, N., (2018), "The determinants of green packaging that influence buyers' willingness to pay a price premium", Australasian Marketing Journal, vol. 26, no. 3, pp. 221-230.

Skarmeas, D., \& Leonidou, C. N., (2013), "When consumers doubt, watch out! The role of CSR scepticism", Journal of Business Research, vol. 66, no. 10, pp. 1831-1838.

Stern, P. C., (2000), "New environmental theories: toward a coherent theory of environmentally significant behaviour", Journal of Social Issues, vol. 56, no. 3, pp. 407-424. 
Sreen, N., Purbey, S., \& Sadarangani, P., (2018), "Impact of culture, behaviour and gender on green purchase intention", Journal of Retailing and Consumer Services, vol. 41, pp. 177-189.

Tam, K. P., Lee, S. L., \& Chao, M. M., (2013), "Saving Mr. nature: Anthropomorphism enhances connectedness to and protectiveness toward nature", Journal of Experimental Social Psychology, vol. 49, no. 3, pp. 514-521.

The Economic Times, (2020), "Inside story: Indoor pollutants more harmful than those in an outdoor environment", Retrieved from: https://economictimes.indiatimes.com/magazi nes/panache/inside-story-indoor-pollutants-more-harmful-than-those-in-an-outdoorenvironment/articleshow/61116446.cms?utm_source=contentofinterest\&utm_medium= text\&utm_campaign=cppst

Thogersen, J., de Barcellos, M. D., Perin, M. G., \& Zhou, Y., (2015), "Consumer buying motives and attitudes towards organic food in two emerging markets: China and Brazil", International Marketing Review, vol. 32, no. 3/4, pp. 389-413.

White, K., \& Simpson, B., (2013), "When do (and don't) normative appeals influence sustainable consumer behaviours?", Journal of Marketing, vol. 77, no. 2, pp. 78-95.

Wilson, E. O., (1984), Biophillia: The human bond with other species, Harvard University Press, London.

Yadav, R., \& Pathak, G. S., (2016), "Young consumers' intention towards buying green products in a developing nation: Extending the theory of planned behaviour", Journal of Cleaner Production, vol. 135, pp. 732-739.

Yadav, R., \& Pathak, G. S., (2017), "Determinants of consumers' green purchase behaviour in a developing nation: Applying and extending the theory of planned behaviour", Ecological Economics, vol. 134, pp. 114-122.

Young, W., Hwang, K., McDonald, S., \& Oates, C. J., (2010), "Sustainable consumption: Green consumer behaviour when purchasing products", Sustainable Development, vol. 18 , no. 1 , pp. 20-31.

Yue, B., Sheng, G., She, S., \& Xu, J., (2020), "Impact of consumer environmental responsibility on green consumption behaviour in China: The role of environmental concern and price sensitivity", Sustainability, vol. 12, no. 5, p. 2074.

Zylstra, M. J., (2014), "Exploring meaningful nature experience, connectedness with nature and the revitalisation of transformative education for sustainability", Doctoral Dissertation, Stellenbosch University, Stellenbosch. 